\title{
Optimization of the production and characterization of milk clotting enzymes by Bacillus subtilis natto
}

\author{
Fang-Chen $\mathrm{Wu}^{1}$, Chen-Wei Chang ${ }^{2}$ and Ing-Lung Shih ${ }^{2^{*}}$
}

\begin{abstract}
Suitable medium for production of milk clotting enzyme (MCE) by Bacillus subtilis (natto) Takahashi in submerged liquid-state fermentation was screened, the nutrient factors affecting MCE production was optimized by response surface methodology. The MCE production by B. subtilis (natto) Takahashi was increased significantly by $428 \%$ in the optimal medium developed. The MCE was filtered and concentrated by ultrafiltration. The retentate after tandem filtration carried out with the combined membranes of MWCO 50kDa and $5 \mathrm{kDa}$ showed two major bands between $25 \mathrm{kDa}$ and $30 \mathrm{kDa}$ on SDS-PAGE, and the MCA and MCA/PA improved significantly in comparison with those in the initial broth. The crude enzyme thus obtained showed MCA and MCA/PA ratio of 48,000 SU/g and 6,400 , which are commensurate with those (MCA 26,667 SU/g and MCA/PA 6,667) of the commercial rennet. It had optimal $\mathrm{pH}$ and temperature at $\mathrm{pH} 6$ and $60^{\circ} \mathrm{C}$, and showed excellent $\mathrm{pH}$ and thermal stability.
\end{abstract}

Keywords: Bacillus subtilis natto, Milk-clotting enzyme, Milk-clotting activity, Cheese making, Ultrafiltration, Response surface methodology

\section{Introduction}

Milk coagulation is a basic step in cheese manufacturing. For a long time calf rennet, the conventional milk clotting enzyme obtained from the fourth stomach of suckling calves (Nagodawithana \& Reed 1993), is the most widely used coagulant in cheese-making all over the world to manufacture most of the cheese varieties. The worldwide reduced supply of calf rennet and the ever increase of cheese production and consumption have stimulated the research for milk clotting enzyme (MCE) from alternative sources to be used as calf rennet substitutes (Areces et al. 1992; Escobar \& Barnett 1993; Lopes et al. 1998; Nouani et al. 2011). Various animals, plants and microbial proteases have been suggested as milk coagulants (Chazarra et al. 2007; D’Ambrosio et al. 2003; Silva \& Malcata 2005; Zhang et al. 2011). However, attention has been focused on the production of milk-clotting enzymes (MCEs) from microbial sources for use as rennin substitutes (Ayhan et al. 2001; Cavalcanti et al. 2004; Hashem

\footnotetext{
*Correspondence: ils@mail.dyu.edu.tw

${ }^{2}$ Department of Environmental Engineering, Da-Yeh University, 168,

University Rd., Dacun, Changhua 51591, Taiwan

Full list of author information is available at the end of the article
}

1999; Silveira et al. 2005). Although there are many microorganisms that produce MCEs (Ding et al. 2011; He et al. 2011; Li et al. 2012; Vishwanatha et al. 2010), only the MCEs produced by strains of Rhizomucor miehei, Rhizomucor pusillus var. Lindt, Aspergillus oryzae and Enthothia parasitica are widely used (Birkkjaer \& Jonk 1985; Crawford 1985; Thakur et al. 1990a).

Bacillus subtilis (natto) Takahashi, a commercial natto starter, is commonly used to prepare fermented soybean product-natto, which is a traditional Japanese food for more than 1,000 years. Bacillus subtilis is one of the most investigated microbial groups, because they can produce varieties of biotechnological interesting substances (Schallmey et al. 2004; Shih \& Yu 2005); it is known to secrete several proteases during the fermentation process (Rao et al. 1998). The capacity of selected Bacillus strains to produce and secrete large quantities of extracellular enzymes has led them to be among the most important industrial enzyme producers. While B. subtilis (natto) produces many enzymes, including amylases and 
cellulases, the most important enzymes in the production of natto are proteases; many of them have been characterized (Yoshimoto et al. 1971). The proteases are responsible for the main flavor, through hydrolysis of soybean protein. It is conceivable that $B$. subtilis (natto) may produce MCE (s). Recently, we have shown that Bacillus subtilis (natto) Takahashi produced milk clotting enzyme (MCE). The Milk-clotting activity (MCA) and milk-clotting activity/ proteolytic activity (MCA/PA) ratio of the crude enzyme obtained are comparable with those of Pfizer microbial rennin and Mucor rennin (Shieh et al. 2009).

Previous works on the optimization of parameters for MCE production were conducted using " one-factor-at -atime" technique (Ayhan et al. 2001; Cavalcanti et al. 2004; Hashem 1999; Silveira et al. 2005). Unfortunately, it frequently fails to locate the region of optimum response because the joint effects of factors on the response are not taken into account in such procedure. It was reported that the complexities and uncertainties associated the largescale microbial fermentation usually come from lack of knowledge of the sophisticated interactions among various factors. The response surface methodology (RSM) has been increasingly used for various phases of an optimization process in fermentation (Shih \& Shen 2006; Shih et al. 2002). It is a powerful technique for testing multiple process variables because fewer experimental trials are needed compared to the study of one variable at a time. In addition, interactions between variables can be identified and quantified by such technique (Box \& Wilson 1951). However, the application of this technique on optimizing the MCE production was scarce in the literature. In the present study, we screened suitable medium for production of MCE and applied RSM to optimize the medium content for the enhancement of MCE production by Bacillus subtilis (natto) Takahashi in submerged liquidstate fermentation (SLF) and characterized the MCE thus produced.

\section{Material and methods}

\section{Bacteria strains and reagents}

B. subtilis (natto) Takahashi was obtained from Takahashi Yuzo research facility Japan. Reagents for cultivation such as nutrient agar (NA), nutrient broth (NB) were purchased from DIFCO Laboratories Michigan, USA. Potassium dihydrogenphosphate $\left(\mathrm{NaH}_{2} \mathrm{PO}_{4}\right)$, sodium nitrate $\left(\mathrm{NaNO}_{3}\right)$, ammonium chloride $\left(\mathrm{NH}_{4} \mathrm{Cl}\right)$, ferrous Sulfate $\left(\mathrm{FeSO}_{4} 7 \mathrm{H}_{2} \mathrm{O}\right)$ and starch were purchased from Katayama Chemical Inc. (Osaka, Japan). Corn steep powder (CSP), $\mathrm{MgSO}_{4} \cdot 7 \mathrm{H}_{2} \mathrm{O}, \mathrm{NaH}_{2} \mathrm{PO}_{4} \cdot 2 \mathrm{H}_{2} \mathrm{O}, \mathrm{Na}_{2} \mathrm{HPO}_{4} 12 \mathrm{H}_{2} \mathrm{O}$, rennin from Rhizomucor miehei (type II) were obtained from Sigma Chemical (St. Louis, MO). Dry skim milk powder was from New Zealand milk brands Ltd. All other reagents used were of the highest grade available unless indicated otherwise.

\section{Fermentation media and conditions Preparation of inoculums}

B. subtilis (natto) Takahashi or other tested Bacillus subtilis (natto) bacteria were first cultured on NA (Difco Laboratories) containing agar $\left(15 \mathrm{~g} \mathrm{l}^{-1}\right)$, beef extract $\left(3 \mathrm{~g} \mathrm{l}^{-1}\right)$, peptone $\left(5 \mathrm{~g} \mathrm{l}^{-1}\right)$ at $37^{\circ} \mathrm{C}$ overnight. The colonies appeared on the plate were picked up (1 cm square) and inoculated into $5 \mathrm{ml}$ of $\mathrm{NB}$ composed of beef extract $\left(3 \mathrm{~g} \mathrm{l}^{-1}\right)$, peptone $\left(5 \mathrm{~g} \mathrm{l}^{-1}\right)$ in a $30 \mathrm{ml}$ test tube. The medium was adjusted to $\mathrm{pH} 7.0$ and then incubated at $37^{\circ} \mathrm{C}$, for $20 \mathrm{~h}$ with shaking at $175 \mathrm{rpm}$. After incubation, $1 \mathrm{ml}$ of bacteria were inoculated into $100 \mathrm{ml}$ medium composed of beef extract $\left(3 \mathrm{~g} \mathrm{l}^{-1}\right)$, peptone $\left(5 \mathrm{~g} \mathrm{l}^{-1}\right)$, soybean $\left(50 \mathrm{~g} \mathrm{l}^{-1}\right)$, sucrose $\left(2 \mathrm{~g} \mathrm{l}^{-1}\right)$ and $\mathrm{NaCl}$ $\left(5 \mathrm{~g} \mathrm{l}^{-1}\right)$ in a $250 \mathrm{ml}$ Erlenmyer flask. The culture broth was adjusted to $\mathrm{pH} 7.0$, incubated at $37^{\circ} \mathrm{C}$ for $20 \mathrm{~h}$ with shaking at $175 \mathrm{rpm}$, which was then used as inoculums for the later experiments.

\section{Liquid state fermentation (LSF)}

In the preliminary experiments, six media were screened for their suitability for MCE production; they included the liquid fermentation medium (designated as LF medium in this paper) used in the previous report (Shieh et al. 2009) and five other different media commonly used by researchers investigating production of MCE by Rhizomucor miehei (Thakur et al. 1990b). LF medium was composed of sucrose $\left(50 \mathrm{~g} \mathrm{l}^{-1}\right), \mathrm{NaCl}\left(10 \mathrm{~g} \mathrm{l}^{-1}\right), \mathrm{MgSO}_{4} \cdot 7 \mathrm{H}_{2} \mathrm{O}\left(0.5 \mathrm{~g} \mathrm{l}^{-1}\right), \mathrm{NaH}_{2}$ $\mathrm{PO}_{4} .2 \mathrm{H}_{2} \mathrm{O}\left(3 \mathrm{~g} \mathrm{l}^{-1}\right)$ and $\mathrm{NaHPO}_{4} \cdot 12 \mathrm{H}_{2} \mathrm{O}\left(3 \mathrm{~g} \mathrm{l}^{-1}\right)$. The other five media were designated as M1, M2, M3, M4 and M5. M1was composed of starch $\left(30 \mathrm{~g} \mathrm{l}^{-1}\right)$, corn steep powder $\left(5 \mathrm{~g} \mathrm{l}^{-1}\right)$, soybean meal $\left(2 \mathrm{~g} \mathrm{l}^{-1}\right)$, dry milk $\left(12 \mathrm{~g} \mathrm{l}^{-1}\right), \mathrm{KH}_{2} \mathrm{PO}_{4}$ $\left(2 \mathrm{~g} \mathrm{l}^{-1}\right), \mathrm{NaNO}_{3}\left(1 \mathrm{~g} \mathrm{l}^{-1}\right), \mathrm{NHCl}_{4}\left(1 \mathrm{~g} \mathrm{l}^{-1}\right)$ and $\mathrm{FeSO}_{4} .7 \mathrm{H}_{2} \mathrm{O}$ $\left(0.01 \mathrm{~g} \mathrm{l}^{-1}\right)$. M2was composed of starch $\left(4 \mathrm{~g} \mathrm{l}^{-1}\right)$, soybean meal $\left(5 \mathrm{~g} \mathrm{l}^{-1}\right), \mathrm{CaCO}_{3}\left(5 \mathrm{~g} \mathrm{l}^{-1}\right)$ and ground barley $\left(10 \mathrm{~g} \mathrm{l}^{-1}\right)$. M3 was composed of glucose $\left(10 \mathrm{~g} \mathrm{l}^{-1}\right)$, soybean meal $\left(30 \mathrm{~g} \mathrm{l}^{-1}\right)$, dry milk $\left(10 \mathrm{~g} \mathrm{l}^{-1}\right), \mathrm{KH}_{2} \mathrm{PO}_{4}\left(0.05 \mathrm{~g} \mathrm{l}^{-1}\right), \mathrm{NaNO}_{3}$ $\left(10 \mathrm{~g} \mathrm{l}^{-1}\right), \mathrm{MgSO}_{4} .7 \mathrm{H}_{2} \mathrm{O}\left(0.025 \mathrm{~g} \mathrm{l}^{-1}\right)$. M4 was composed of rice bran $\left(100 \mathrm{~g} \mathrm{l}^{-1}\right)$, soybean meal $\left(10 \mathrm{~g} \mathrm{l}^{-1}\right)$, rice flour $\left(10 \mathrm{~g} \mathrm{l}^{-1}\right), \mathrm{CaCl}_{2} \cdot 7 \mathrm{H}_{2} \mathrm{O}\left(10 \mathrm{~g} \mathrm{l}^{-1}\right)$. M5 was composed of starch $\left(100 \mathrm{~g} \mathrm{l}^{-1}\right)$, lactose $\left(4.3 \mathrm{~g} \mathrm{l}^{-1}\right)$, soybean meal $\left(30 \mathrm{~g} \mathrm{l}^{-1}\right)$, yeast extract $\left(3 \mathrm{~g} \mathrm{l}^{-1}\right), \mathrm{MgSO}_{4} \cdot 7 \mathrm{H}_{2} \mathrm{O}\left(0.025 \mathrm{~g} \mathrm{l}^{-1}\right)$. The culture media were steamed and sterilized in autoclave at $121^{\circ} \mathrm{C}$ for $15 \mathrm{~min}$. Each medium was inoculated with $5 \mathrm{ml}$ $(5 \%, \mathrm{v} / \mathrm{v})$ of bacteria inoculums prepared above and adjusted to $\mathrm{pH} 7.0$, followed by incubation at $37^{\circ} \mathrm{C}$ with shaking at $175 \mathrm{rpm}$ for $72 \mathrm{~h}$. At the end of incubation, the culture medium was filtered through the cotton cloth to remove insoluble, which was followed by centrifugation at $5,600 \times \mathrm{g}, 4^{\circ} \mathrm{C}$ for $20 \mathrm{~min}$ to remove the bacteria and the supernatant was then filtered through a $0.45 \mu \mathrm{m}$ filter. The liquid broth of the crude enzyme was used to assay for milk-clotting activity. To investigate the factors affecting MCE production, the cultivation was carried out using the medium and conditions indicated above except that 
the factors were varied by experimental design described below.

\section{Assay for milk clotting activity}

Milk clotting activity was determined according to the method of Arima (Arima et al. 1970) and expressed in terms of Soxhlet units (SU). One SU is defined as the amount of enzyme which clots $1 \mathrm{ml}$ of a solution containing $0.1 \mathrm{~g}$ skim milk powder and $0.00111 \mathrm{~g}$ calcium chlorides in $40 \mathrm{~min}$ at $35^{\circ} \mathrm{C}$. In brief, $0.5 \mathrm{ml}$ of tested materials was added to a test-tube containing $5 \mathrm{ml}$ of reconstituted skim milk solution (10g dry skim milk/ $100 \mathrm{ml}, 0.01 \mathrm{M} \mathrm{CaCl}_{2}$ ) pre-incubated at $35^{\circ} \mathrm{C}$ for $5 \mathrm{~min}$. The mixture was mixed well and the clotting time $\mathrm{T}(\mathrm{sec})$, the time period starting from the addition of test material to the first appearance of clots of milk solution, was recorded and the clotting activity was calculated using the following formula: $\mathrm{SU}=2400 \times 5 \times \mathrm{DD} / \mathrm{T} \times 0.5 ; \mathrm{T}=$ clotting time (sec); D=Dilution of test material. The test materials include liquid solution of crude enzyme from LSF and commercial rennet of Rhizomucor miehei.

\section{Assay of protease activity}

The proteolytic activity was determined at $\mathrm{pH} 6.5$ by the casein digestion method (Kunitz 1947) and expressed as optical density (OD) at $660 \mathrm{~nm}$. Ratio of the milk-clotting activity to proteolytic activity is expressed as milk-clotting units $(\mathrm{SU})$ versus the $\mathrm{OD}_{660}$ 's obtained in the proteolytic measurements.

\section{Protein determination}

Protein determination was done according to the method of Lowry et al (Lowry et al. 1951).

\section{RSM Experimental design}

In preliminary studies (Chang 2010; Shieh et al. 2009), we used "one-factor-at-a-time" technique to evaluate various factors for their suitability to sustain good production of MCE by B. subtilis (natto) Takahashi. The preliminary data suggested that starch $\left(\mathrm{X}_{1}\right)$, corn steep powder $\left(\mathrm{X}_{2}\right)$, soybean meal $\left(\mathrm{X}_{3}\right)$ and dry milk $\left(\mathrm{X}_{4}\right)$ were the major variables (Chang 2010). As is seen below (Results and discussions), the preliminary result shows that MCA was 600 $\mathrm{SU} / \mathrm{ml}$ when B. subtilis (natto) Takahashi was incubated in M1 in which starch, corn steep powder, soybean meal and dry milk was $30 \mathrm{~g} \mathrm{l}^{-1}, 5 \mathrm{~g} \mathrm{l}^{-1}, 2 \mathrm{~g} \mathrm{l}^{-1}$ and $12 \mathrm{~g} \mathrm{l}^{-1}$, respectively. Therefore, these four factors were chosen for further optimization through RSM.

\section{Factorial design}

In the first experiment of this series, the ranges of the variables tested were starch $\left(30 \mathrm{~g} \mathrm{l}^{-1}\right)$, corn steep powder $\left(5 \mathrm{~g} \mathrm{l}^{-1}\right)$, soybean meal $\left(2 \mathrm{~g} \mathrm{l}^{-1}\right)$ and dry milk $\left(12 \mathrm{~g} \mathrm{l}^{-1}\right)$. For a $2^{4}$ factorial design with four factors at two levels, sixteen experimental runs are required (Box \& Wilson 1951). Two center points were added to estimate the experimental error and check the adequacy of the firstorder model. Although two-level (full or fractional) factorial experiments will only yield data to fit a limited model (equation 1 or 2), they are the most common initial experiments in the application of RSM, because orthogonality of the design minimizes the variance of the regression coefficients (Maddox \& Richert 1977; Montgomery 1991). Table 1 shows the four independent variables and their concentrations at the different coded levels of the factorial design experiments. The matrix corresponding to the $2^{4}$ factorial designs, together with the observed experimental data and predicted values from model equation are also shown in Table 1. To avoid bias, the total of 18 runs was performed in a random order (overall randomization).

$$
\begin{aligned}
& Y=\beta_{0}+\sum_{i=1}^{k} \beta_{i} x_{i} \\
& Y=\beta_{0}+\sum_{i=1} \beta_{i} x_{i}+\sum_{i<j}^{k} \sum \beta_{i j} x_{i} x_{j}
\end{aligned}
$$

$\mathrm{Y}$ is the predicted response (MCA in this study, $\mathrm{SU} / \mathrm{ml}$ ); $\beta_{0}, \beta_{i}, \beta_{i j}$ are constant coefficients, and $x_{i}, x_{j}$ are the coded independent variables or factors.

\section{Central composite design (CCD)}

Based on the results obtained from the factorial design, Box-Wilson central composite design (CCD) was used to optimize the levels of variables, which can help to identify and quantify the interaction between variables (Box \& Wilson 1951). In addition, to fully explore the subregion of the response surface in the neighborhood of the optimum, an experimental design with more than two levels of each factor is required, so that a second order approximation to the response surface can be developed; a CCD with five coded levels was used for this purpose. The four factors are starch $\left(\mathrm{X}_{1}\right)$, corn steep powder $\left(\mathrm{X}_{2}\right)$, soybean meal $\left(\mathrm{X}_{3}\right)$ and dry milk $\left(\mathrm{X}_{4}\right)$ and the levels of the variables for the CCD experiments were chosen in reconciliation with the data of our previous experiments. For the four factors, this trial was essentially a full $2^{4}$ factorial design augmented by eight axial points (or called star points) coded $\pm \alpha$ and three replications of center point (all factors at level 0), resulting in a total number of 27 experiments (Box \& Wilson 1951). The distance of the star points from the centrepoint is given by $\alpha=2^{\mathrm{n} / 4}$ (for four factors $\mathrm{n}=4, \alpha=2.0$ ). For predicting the optimal point, the experimental data of a $\mathrm{CCD}$ are usually used to fit a second-order polynomial equation (equation 3), as it gives a complete picture including any possible interaction between the values. The matrix corresponding to the CCD is shown in Table 2, 
Table 1 Experimental design and results of the four-factor-two-level factorial design together with the predicted yields from the pure first-order model

\begin{tabular}{|c|c|c|c|c|c|c|}
\hline $\begin{array}{l}\text { Factors }^{a} \\
\text { Trial no. }\end{array}$ & $X_{1}(g / L)$ & $X_{2}(g / L)$ & $X_{3}(g / L)$ & $X_{4}(g / L)$ & $\begin{array}{l}\text { Observed MCA } \\
\quad(\mathrm{SU} / \mathrm{mL})\end{array}$ & $\begin{array}{l}\text { Predicted MCA } \\
\quad(\mathrm{SU} / \mathrm{mL})\end{array}$ \\
\hline 1 & 10 & 2 & 1 & 8 & 28.57 & 84.1162 \\
\hline 2 & 50 & 2 & 1 & 8 & 533.33 & 639.2012 \\
\hline 3 & 10 & 8 & 1 & 8 & 12.31 & -31.3188 \\
\hline 4 & 50 & 8 & 1 & 8 & 505.26 & 523.7662 \\
\hline 5 & 10 & 2 & 3 & 8 & 40 & 86.6212 \\
\hline 6 & 50 & 2 & 3 & 8 & 685.71 & 641.7063 \\
\hline 7 & 10 & 8 & 3 & 8 & 25.8 & -28.8138 \\
\hline 8 & 50 & 8 & 3 & 8 & 417.39 & 526.2712 \\
\hline 9 & 10 & 2 & 1 & 16 & 64 & 142.4388 \\
\hline 10 & 50 & 2 & 1 & 16 & 738.46 & 697.5237 \\
\hline 11 & 10 & 8 & 1 & 16 & 25 & 27.0037 \\
\hline 12 & 50 & 8 & 1 & 16 & 564.71 & 582.0888 \\
\hline 13 & 10 & 2 & 3 & 16 & 53.33 & 144.9438 \\
\hline 14 & 50 & 2 & 3 & 16 & 800 & 700.0288 \\
\hline 15 & 10 & 8 & 3 & 16 & 12.31 & 29.5088 \\
\hline 16 & 50 & 8 & 3 & 16 & 457.14 & 584.5938 \\
\hline${ }^{b} 17(C)$ & 30 & 5 & 2 & 12 & 533.33 & 334.355 \\
\hline${ }^{b} 18(C)$ & 30 & 5 & 2 & 12 & 521.74 & 334.355 \\
\hline
\end{tabular}

${ }^{a}$ Starch $\left(X_{1}\right)$, Corn steep powder $\left(\mathrm{X}_{2}\right)$, Soybean meal $\left(\mathrm{X}_{3}\right)$ and Dry milk $\left(\mathrm{X}_{4}\right) ;{ }^{\mathrm{b}}$ Centrepoints.

together with the observed experimental data and predicted values from the model equation.

$$
Y=\beta_{0}+\sum_{i=1}^{k} \beta_{i} x_{i}+\sum_{i=1}^{k} \beta_{i i} x_{I} x_{j}+\sum_{i<j} \sum \beta_{i j} x_{i} x_{j}
$$

$\mathrm{Y}$ is the predicted response (MCA in this study, SU/ml); $\beta_{0}, \beta_{\mathrm{i}}, \beta_{\mathrm{ii}}$

$\beta_{\mathrm{ij}}$ are constant coefficients, and $\mathrm{x}_{\mathrm{i}}, \mathrm{x}_{\mathrm{j}}$ are the coded independent variables or factors.

\section{Software for experimental design and statistical analysis}

Statistica, version 6.0 (Statsoft, Inc., Tulsa, OK USA) was used for the experimental design and regression analysis of the experimental data obtained. The quality of fit of the model equation was expressed by the coefficient of determination $\mathrm{R}^{2}$, and its statistical significance was determined by an F-test. The significance of the regression coefficients was tested by a t-test. For analysis of the nature of the fitted response and for prediction of the maximum point, the second-order equation was reduced to its canonical form (Maddox \& Richert 1977; Montgomery 1991). Canonical analysis was one part of the Statistica output.

\section{Concentration of MCE by ultrafiltration}

The cell-free supernatant of the culture was cycled though a Tami ultrafiltration membrane system equipped with various ceramic membranes (the molecular weight cut-off (MWCO); 1kDa, 5 kDa, $50 \mathrm{kDa}$, Quebec, Canada). The apparatus was operated with a transmembrane pressure (TMP) of $100 \mathrm{psi}$, and room temperatures between 20 and $35^{\circ} \mathrm{C}$. During the separation, the product is fractionated in two phases: the concentrated retentate and the filtrate. Both concentrated retentate and the filtrate were used to assay for milk-clotting activity as described above, and their protein contents were determined according to the method of Lowry (Lowry et al. 1951). The molecular weight of MCE was determined by sodium dodecyl sulfate-polyacryamide gel electrophoresis (SDS-PAGE) according to the method of Weber and Osborn (Weber \& Osborn 1969).

\section{pH and thermal stability}

The thermal stability was determined by pre-incubating the enzyme in the temperature range of $40-80^{\circ} \mathrm{C}$. The incubation time of samples varied from 5 to $120 \mathrm{~min}$. After incubation, the samples were submitted for determination of residual milk-clotting activity. To study the $\mathrm{pH}$ stability of MCE produced by B. subtilis (natto) Takahashi, the enzyme was held at $35^{\circ} \mathrm{C}$, different $\mathrm{pH}$ levels ( $\left.\mathrm{pH} 5-10\right)$ for up to $72 \mathrm{~h}$, followed by activity assay as described above. 
Table 2 Experimental design and results of the central composite design together with predicted yields from the model equation

\begin{tabular}{|c|c|c|c|c|c|c|}
\hline $\begin{array}{c}\text { Factors }^{a} \\
\text { Trial }\end{array}$ & $X_{1}(g / L)$ & $X_{2}(g / L)$ & $X_{3}(g / L)$ & $X_{4}(g / L)$ & MCA (SU/mL) & $\begin{array}{c}\text { Predicted } \\
\text { Values }\end{array}$ \\
\hline 1 & 20 & 3 & 1.5 & 8 & 40.00 & 99.639 \\
\hline 2 & 40 & 3 & 1.5 & 8 & 600.00 & 600.917 \\
\hline 3 & 20 & 7 & 1.5 & 8 & 20.00 & 85.639 \\
\hline 4 & 40 & 7 & 1.5 & 8 & 533.33 & 534.747 \\
\hline 5 & 20 & 3 & 2.5 & 8 & 133.33 & 231.47 \\
\hline 6 & 40 & 3 & 2.5 & 8 & 800.00 & 783.084 \\
\hline 7 & 20 & 7 & 2.5 & 8 & 80.00 & 120.305 \\
\hline 8 & 40 & 7 & 2.5 & 8 & 600.00 & 619.749 \\
\hline 9 & 20 & 3 & 1.5 & 16 & 233.33 & 297.304 \\
\hline 10 & 40 & 3 & 1.5 & 16 & 800.00 & 826.417 \\
\hline 11 & 20 & 7 & 1.5 & 16 & 25.00 & 108.639 \\
\hline 12 & 40 & 7 & 1.5 & 16 & 600.00 & 585.582 \\
\hline 13 & 20 & 3 & 2.5 & 16 & 333.33 & 398.635 \\
\hline 14 & 40 & 3 & 2.5 & 16 & 960.00 & 978.084 \\
\hline 15 & 20 & 7 & 2.5 & 16 & 30.00 & 112.805 \\
\hline 16 & 40 & 7 & 2.5 & 16 & 633.33 & 640.084 \\
\hline 17 & 10 & 5 & 2 & 12 & 30.00 & -174.501 \\
\hline 18 & 50 & 5 & 2 & 12 & 800.00 & 854.056 \\
\hline 19 & 30 & 1 & 2 & 12 & 700.00 & 617.442 \\
\hline 20 & 30 & 9 & 2 & 12 & 333.33 & 265.442 \\
\hline 21 & 30 & 5 & 1 & 12 & 450.00 & 381.611 \\
\hline 22 & 30 & 5 & 3 & 12 & 650.00 & 567.944 \\
\hline 23 & 30 & 5 & 2 & 4 & 450.00 & 390.777 \\
\hline 24 & 30 & 5 & 2 & 20 & 700.00 & 608.777 \\
\hline${ }^{b} 25(C)$ & 30 & 5 & 2 & 12 & 533.33 & 542.167 \\
\hline${ }^{b} 26(C)$ & 30 & 5 & 2 & 12 & 571.43 & 542.167 \\
\hline${ }^{b} 27(C)$ & 30 & 5 & 2 & 12 & 521.74 & 542.167 \\
\hline
\end{tabular}

${ }^{\mathrm{a} S t a r c h}\left(\mathrm{X}_{1}\right)$, Corn steep powder $\left(\mathrm{X}_{2}\right)$, Soybean meal $\left(\mathrm{X}_{3}\right)$ and Dry milk $\left(\mathrm{X}_{4}\right) ;{ }^{\mathrm{b}}$ Centrepoints.

The buffers used were according to the method described previously (Vishwanatha et al. 2010).

\section{Results and discussion}

Screening of suitable medium for MCE production in LSF by B. subtilis (natto) Takahashi

Previously, it was shown that B. subtilis (natto) Takahashi produced MCE in LF medium, the milk-clotting activity (MCA) and milk-clotting activity/proteolytic activity (MCA/PA) ratio of the crude enzyme obtained were comparable with those of Pfizer microbial rennin and Rhizomucor rennin (Shieh et al. 2009). Therefore, it is a strain that showed potential for further study to produce industrial useful MCE as a calf rennet substitutes. M1, M2, M3, M4 and M5 indicated above were the media of choice for researchers investigating production of MCE by Rhizomucor miehei (Thakur et al. 1990b). They were tested for the suitability of MCE production by B. subtilis (natto) Takahashi, and the results are shown in Table 3. The highest MCA and MCA/PA ratio $(600 \mathrm{SU} / \mathrm{ml}$ and 4,878 ) reached was for the cultivation in M1, which is inconsistent with the results shown for Rhizomucor miehei in that the highest MCA $(1,482 \mathrm{SU} / \mathrm{ml})$ reached was for its cultivation in M2 (Thakur et al. 1990b). In addition, the highest MCA and MCA/PA ratio $(600 \mathrm{SU} / \mathrm{ml}$ and 4,878 ) reached when $B$. subtilis (natto) Takahashi was cultured in M1 were comparable and improved in comparison with those $(685 \mathrm{SU} / \mathrm{ml}$ and 2,981) obtained when it was cultured in LF medium previously used (Shieh et al. 2009). As shown in Figure 1, when the B. subtilis (natto) Takahashi were cultivated in M1, the MCA increased dramatically after $36 \mathrm{~h}$ of cultivation to reach a maximum value 
Table 3 Comparison of MCE produced by B. subtilis (natto) Takahashi in various medium with its commercial counterparts

\begin{tabular}{|c|c|c|c|}
\hline Medium $^{\mathrm{a}}$ & Milk-clotting activity $\left(\frac{\mathrm{SU}}{\mathrm{ml}}\right)$ & Protease activity $\left(\mathrm{OD}_{660}\right)$ & Ratio $\left(\frac{\mathrm{MCA}}{\mathrm{PA}}\right)$ \\
\hline M1 & $600 \pm 12$ & $0.123 \pm 0.012$ & $4878 \pm 476$ \\
\hline M2 & $26.67 \pm 2.10$ & $0.050 \pm 0.006$ & $533 \pm 64$ \\
\hline M3 & $(t>40 \mathrm{~min})$ & $0.043 \pm 0.011$ & NA \\
\hline M4 & $160 \pm 10$ & $0.076 \pm 0.015$ & $2105 \pm 451$ \\
\hline M5 & $80 \pm 4$ & $0.027 \pm 0.008$ & $2963 \pm 877$ \\
\hline LF & $685 \pm 14$ & $0.230 \pm 0.028$ & $2981 \pm 367$ \\
\hline \multicolumn{4}{|c|}{ Commercial Protease } \\
\hline Mucor rennin & $511 \pm 13$ & $0.11 \pm 0.02$ & $4650 \pm 845$ \\
\hline P- Rennin ${ }^{b, c}$ & 750 & 0.29 & 2590 \\
\hline Papain $^{c}$ & 216 & 0.59 & 367 \\
\hline Pepsin ${ }^{c}$ & 2 & 0.015 & 133 \\
\hline
\end{tabular}

at $72 \mathrm{~h}$ of cultivation and then declined, this is consistent with the results obtained for Rhizomucor miehei cultivated in M1, M2, M3 and M4 medium. To further optimize the MCE production by B. subtilis (natto) Takahashi in M1 medium, the effects of some important nutrient parameters on the productions of MCE were investigated by RSM.

\section{Optimization of MCE production by B. subtilis (natto) Takahashi in M1 medium using RSM}

Application of RSM requires the identification of the major factors that are suitable to sustain good production of MCE. In the preliminary studies of MCE production by $B$. subtilis (natto) Takahashi in LF and M1 medium (Chang 2010; Shieh et al. 2009), it appeared that B. subtilis (natto) Takahashi would produce milk-clotting enzyme under the condition of limited organic nitrogen supply and oversupply of inorganic nitrogen sources inhibited the production of milk-clotting activities by this bacterium, a phenomenon that was sustained by the similar observation in the MCE production by a variety of other microorganisms such as Rhizomucor miehei (Thakur et al. 1990a), Streptomyces clavuligerus (Porto et al. 1996), Aspergillus versicolor (Abdel-Fattah \& Saleh 1979) and Mucor baciliformis (Areces et al. 1992). In addition, it was also found that carbon sources were critical for MCE production by B. subtilis (natto) Takahashi. However, the requirement of carbon source for MCE production varied depending on the microorganism used (Abdel-Fattah \& Saleh 1979; Cavalcanti et al. 2005; Hashem 1999; Shieh et al. 2009). Therefore, starch $\left(\mathrm{X}_{1}\right)$, corn steep powder $\left(\mathrm{X}_{2}\right)$, soybean meal $\left(X_{3}\right)$ and dry milk $\left(X_{4}\right)$ were the major variables in M1 affecting the performance of the culture in terms of MCE production, and they were chosen for optimization by RSM; the inorganic nitrogen sources were omitted for further study. Initially, a complete four-factor-two-level factorial design was carried out, which was followed by the central composite design (CCD) to optimize the factors for MCE production.

\section{Results of factorial experiments}

The experimental results of MCE productions are shown in Table 1 . In order to approach the vicinity of the optimum, a first-order model was fitted to the data obtained from the factorial design experiment. From the analysis of the data in Table 1 by the least-squares method, the regression coefficients and corresponding $\mathrm{t}$ values for the model were obtained. Accordingly, the fitted model with coded variables is shown in equation 4.

Pure First-order Model

$$
\mathrm{Y}_{(\mathrm{MCA}, \mathrm{SU} / \mathrm{ml})}=-76+13.9 X_{1}-19.2 X_{2}+1.3 X_{3}+7.3 X_{4}
$$

According to the analyses of variances (ANOVA), F value for the overall regression is significant at 5\% level and the lack of fit is insignificant indicating that the pure first-order model is very adequate in approximating the response surface of the experimental design. This statement is further supported by the satisfactory value of the coefficient of determination $\mathrm{R}^{2}(0.8945)$. Judging from the regression coefficients and the corresponding $t$ values, it is concluded that the linear terms of starch, corn steep powder and dry milk had significant effect on MCE production; it is predicted that increasing the concentration of starch $\left(\mathrm{X}_{1}\right)$, dry milk $\left(\mathrm{X}_{4}\right)$ and decreasing the concentration of corn steep powder $\left(\mathrm{X}_{2}\right)$ should enhance MCE production. In contrast, the soybean meal $\left(\mathrm{X}_{3}\right)$ at the tested range exhibited insignificant effect on MCE production.

\section{Results of CCD experiments}

By applying multiple regression analysis on the experimental data shown in Table 2, the experimental results 


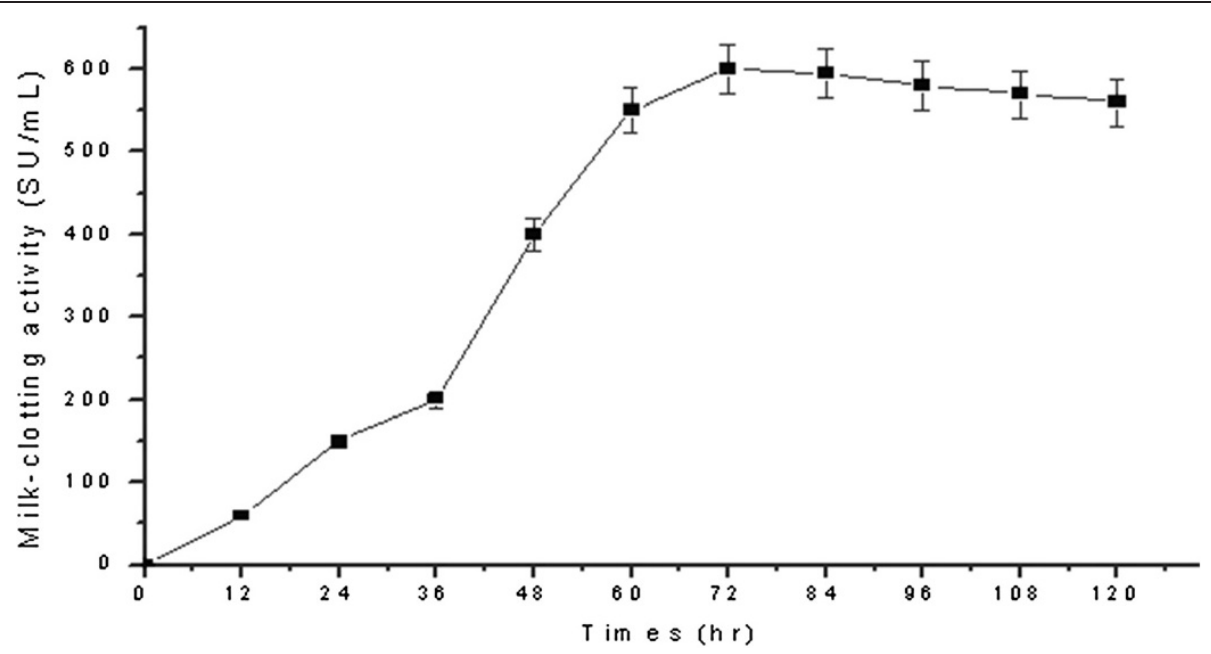

Figure 1 Time course of milk-clotting activities produced by Bacillus subtilis (natto) Takahashi in medium M1.

of the CCD were fitted with the polynomial equation 3, and the second-order polynomial equation obtained is shown in equation 5 .

Second-order Model Equation

$$
\begin{aligned}
\mathrm{Y}_{(\mathrm{MCA}, \mathrm{SU} / \mathrm{ml})}= & 542.17+257.14 X_{1}-88.0 X_{2} \\
& +46.58 X_{3}+54.50 X_{4}-50.60 X_{1}^{2} \\
& -88.0 X_{2}^{2}-16.85 X_{3}^{2}-10.60 X_{4}^{2} \\
& -13.04 X_{1} X_{2}+12.58 X_{1} X_{3}+6.96 X_{1} X_{4} \\
& -24.29 X_{2} X_{3}-43.67 X_{2} X_{4}-7.63 X_{3} X_{4}
\end{aligned}
$$

Judging from the regression coefficients and corresponding $\mathrm{t}$ values, it was concluded that the linear term of starch $\left(\mathrm{X}_{1}\right)$, corn steep powder $\left(\mathrm{X}_{2}\right)$, soybean meal $\left(\mathrm{X}_{3}\right)$ and dry milk $\left(\mathrm{X}_{4}\right)$ and the cross term of starch $\left(\mathrm{X}_{1}\right)$ displayed significant effect on MCE production at a $5 \%$ level $(\mathrm{p}<0.05)$. However, all the other terms were not significant at a $5 \%$ level. The fit of the model was checked by the coefficient of determination $\mathrm{R}^{2}$, which was calculated to be 0.9416 , indicating that $94.16 \%$ of the variability in the response could be explained by the model. According to the analysis of variance (ANOVA), the test statistics $\mathrm{F}$ values for the overall regression is significant at the upper $5 \%$ level, which further supported that the second-order model is very adequate in approximating the response surface of the experimental design. For the analysis of the fitted surface, equation 5 was transformed into its canonical form (equation 6).

$$
\begin{aligned}
\mathrm{Y}-142.17= & -0.51 Z_{1}^{2}-0.66 Z_{2}^{2}-6.30 Z_{3}^{2} \\
& -67.39 Z_{4}^{2}
\end{aligned}
$$

The coefficients of the equation 6 are eigenvalues based on coded data, and $\mathrm{Y}$ is the MCA $(\mathrm{SU} / \mathrm{ml})$. Since all coefficients of the above equation are all negative, the response surface is suggested to have a maximum point (1048.02 SU/ml) where the optimum combination of concentration is starch $55.41 \mathrm{~g} \mathrm{l}^{-1}$, corn steep powder $1.5 \mathrm{~g} \mathrm{l}^{-1}$, soybean meal $2.69 \mathrm{~g} \mathrm{l}^{-1}$ and dry milk $22.29 \mathrm{~g} \mathrm{l}^{-1}$, respectively. Verification of the calculated maximum was done with experiments that were performed in the culture media representing the optimum combination found, and the MCE production of $1043.48 \mathrm{SU} / \mathrm{ml}$ (average of three repeats) was obtained. The excellent correlation between predicted and experimental values justifies the validity of the response model.

Table 4 Properties of various samples from fractionation by ultrafiltration

\begin{tabular}{ccccc}
\hline $\begin{array}{c}\text { Activity } \\
\text { Fraction }\end{array}$ & MCA $(\mathbf{S U} / \mathbf{m L})$ & Protein Con. $(\mathbf{m g} / \mathbf{m L})$ & Proteolytic activity $($ OD660) & MCA/PA Ratiio \\
\hline Initial Broth & $960 \pm 9$ & $0.188 \pm 0.006$ & $0.115 \pm 0.003$ & $8348 \pm 231$ \\
Concentrated Retentate & $3200 \pm 80^{\mathrm{a}}(480 \pm 12)^{\mathrm{b}}$ & $0.231 \pm 0.005^{\mathrm{a}}(0.174 \pm 0.008)^{\mathrm{b}}$ & $0.108 \pm 0.004^{\mathrm{a}}(0.104 \pm 0.003)^{\mathrm{b}}$ & $29630 \pm 1323^{\mathrm{a}}(4615 \pm 176)^{\mathrm{b}}$ \\
Filtrate & $228 \pm 11^{\mathrm{a}}(1200 \pm 25)^{\mathrm{b}}$ & $0.116 \pm 0.010^{\mathrm{a}}(0.224 \pm 0.009)^{\mathrm{b}}$ & $0.089 \pm 0.004^{\mathrm{a}}(0.111 \pm 0.005)^{\mathrm{b}}$ & $2561 \pm 168^{\mathrm{a}}(10811 \pm 535)^{\mathrm{b}}$ \\
\hline
\end{tabular}

${ }^{a}$ Values calculated for samples obtained using membrane having MWCO $5 \mathrm{kDa}$.

bValues (in the parenthesis) calculated for samples obtained using membrane having MWCO 50 kDa. 


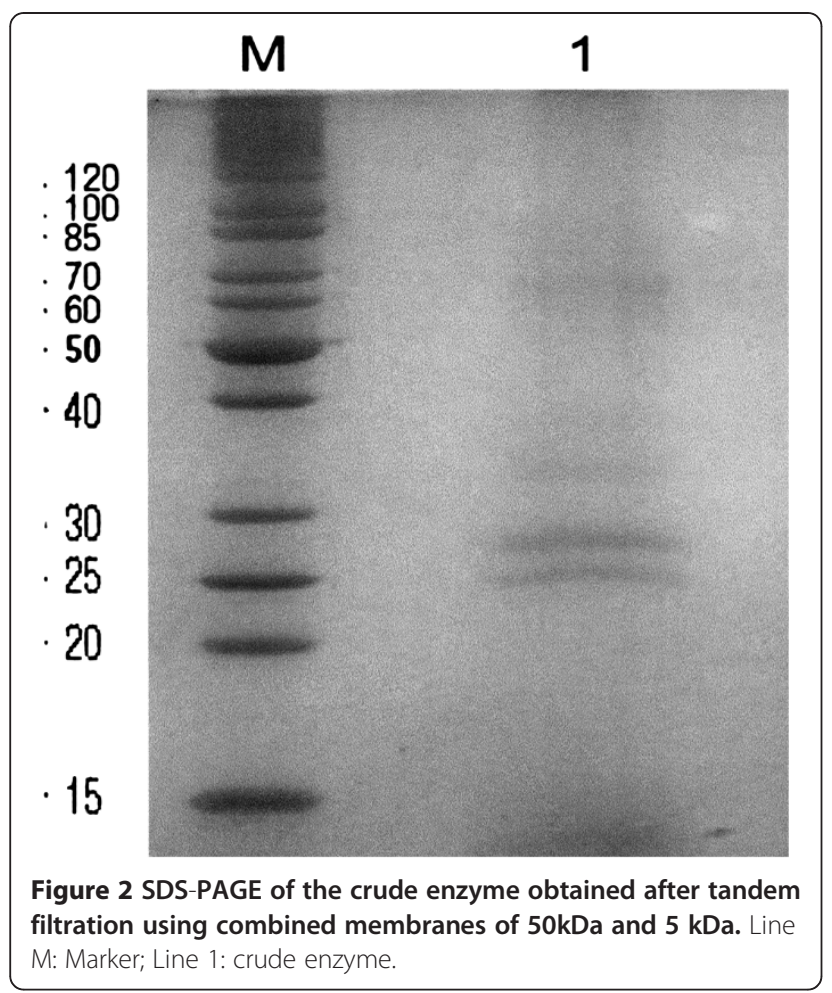

\section{Concentration of MCE by ultrafiltration and its characterization}

Properties of various samples from fractionation by ultrafiltration, which was cycling cell-free supernatant of the culture through MWCO of $5 \mathrm{kDa}$ and $50 \mathrm{kDa}$ membranes, are shown in Table 4. The data showed that after filtering through MWCO of $5 \mathrm{kDa}$ membrane, the MCA and MCA/PA of the retentate was 3.33-fold and 3.54fold of those in the initial broth supernatant; the MCA and MCA/PA of the filtrate however was 0.24-fold and 0.31 -fold of those in the initial broth supernatant, indicating that the majority of MCE was retained within the $5 \mathrm{kDa}$ membrane. In contrast, after filtering through MWCO of $50 \mathrm{kDa}$ membrane, the MCA and MCA/PA of the retentate was 0.5 -fold and 0.55 -fold of those in the initial broth supernatant; the MCA and MCA/PA of the filtrate however was 1.25-fold and 1.30-fold of those in the initial broth supernatant, indicating that most of MCE was filtered through the $50 \mathrm{kDa}$ membrane. When tandem filtration was carried out with the combined membranes of $50 \mathrm{kDa}$ and $5 \mathrm{kDa}$, the SDS-PAGE of the retentate showed two major bands between $25 \mathrm{kDa}$ and $30 \mathrm{kDa}$ (Figure 2), which is comparable with many MCE reported in the literature; Shindo and Arima (Shindo \& Arima 1979) reported molecular weight of calf chymosin to be $35 \mathrm{kDa}$ by SDS-PADE. Similarly, molecular weight has been reported to be $36 \mathrm{kDa}$ and $37.5 \mathrm{kDa}$ for lamb chymosin (Baudys et al. 1988; Rogelj et al. 2001). In addition, it was reported that purified MCE of Bacillus sphaericus appeared as two bands having molecular mass of 25 and $47 \mathrm{kDa}$ on SDS-PAGE (ElBendary et al. 2007); the molecular weight of partially purified MCE of Amylomyces rouxii is about $47.5 \mathrm{kDa}$ infered from SDSPAGE and Native-PAGE, $48.6 \mathrm{kDa}$ inferred from gel filtration (Yu \& Chou 2005).

The retentate after tandem filtration carried out with the combined membranes of $50 \mathrm{kDa}$ and $5 \mathrm{kDa}$ was further lyophilized, the crude MCE powder obtained was re-dissolved

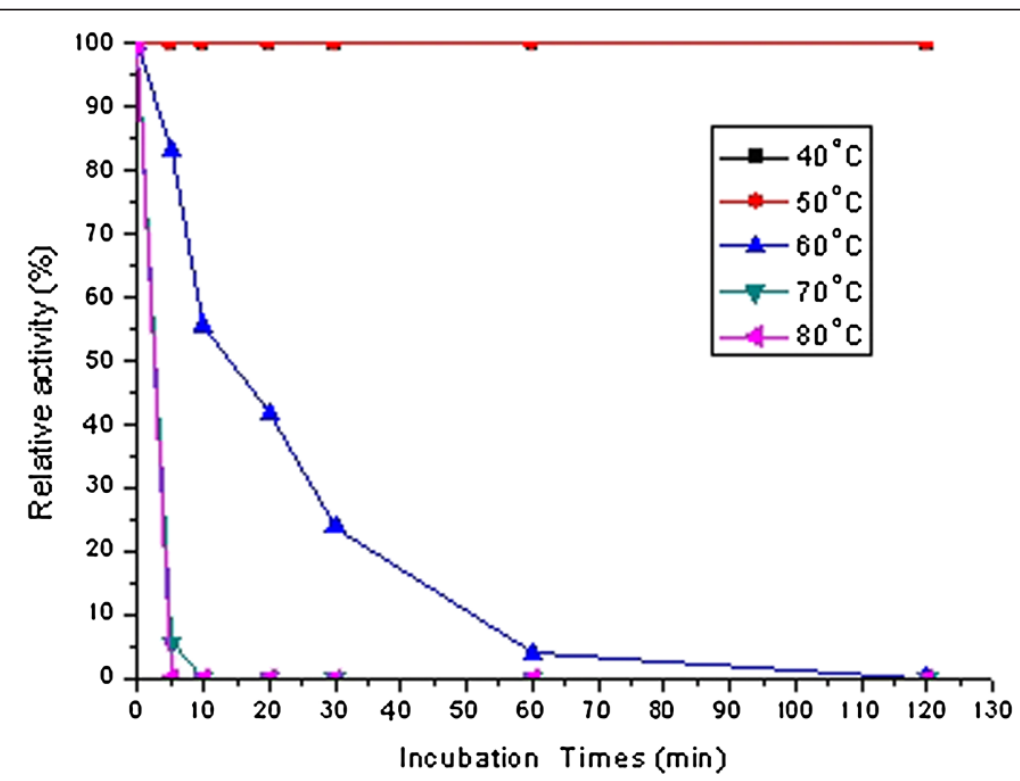

Figure 3 Thermal-stability of milk-clotting enzyme produced by Bacillus subtilis (natto) Takahashi. 


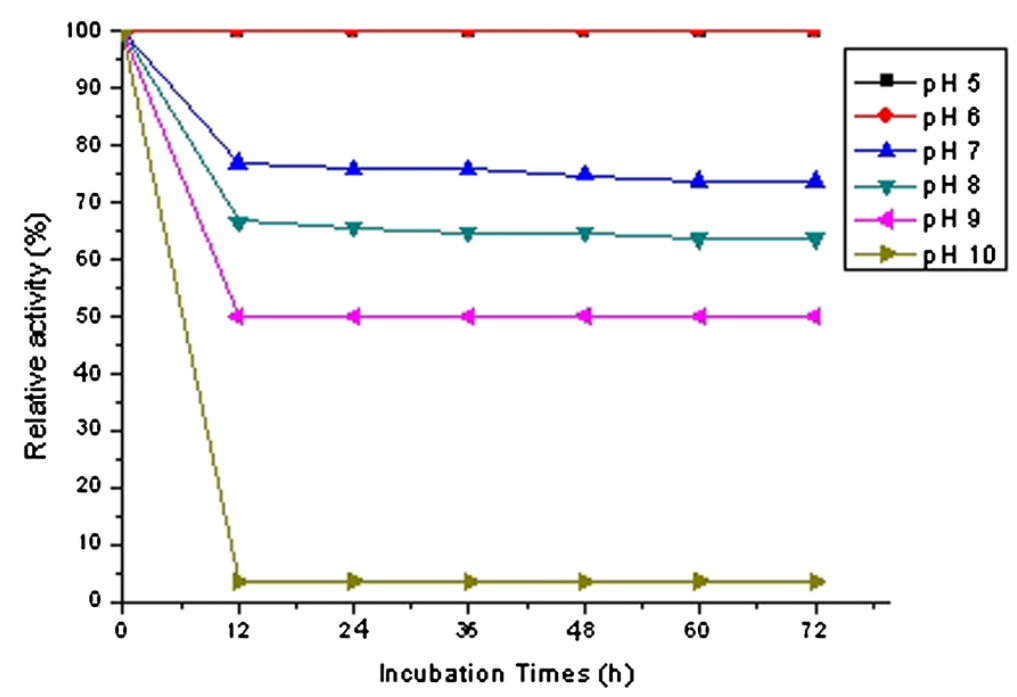

Figure $4 \mathrm{pH}$-stability of milk-clotting enzyme produced by Bacillus subtilis (natto) Takahashi.

and tested for the enzyme activity. The MCA and MCA/ PA ratio of the crude enzyme thus obtained was 48,000 $\mathrm{SU} / \mathrm{g}$ and 6,400 (data not shown), which are commensurate with those (MCA 26,667 SU/g and MCA/PA 6,667) of the commercial rennet from Sigma.

\section{pH and thermal stability}

The enzyme obtained above had optimal pH and temperature at $\mathrm{pH} 6$ and $60^{\circ} \mathrm{C}$ (data not shown), and it showed excellent thermal and $\mathrm{pH}$ stability (Figures 3 and 4). The enzyme completely retained its MCA even after incubation for more than $2 \mathrm{~h}$ at $\mathrm{pH} 6$, and temperature at $40^{\circ} \mathrm{C}$ and $50^{\circ} \mathrm{C}$ (Figure 3 ). However, the MCA decreased dramatically when temperature increased; the enzyme lost $50 \%$ of MCA after it was incubated at $60^{\circ} \mathrm{C}$ for $20 \mathrm{~min}$ and it was deactivated completely at temperature more than $70^{\circ} \mathrm{C}$ within 10 min of incubation. The MCE by B. subtilis (natto) Takahashi shown in this study sustained higher thermalstability than those by various microorganisms. The MCE(s) by P. oxalicum (Hashem 2000), M. pusillus (Khan et al. 1979) and Mucor J20 (Tubesha \& Al-Delaimy 2003) were completely inactivated upon heating at temperature higher than $55^{\circ} \mathrm{C}$ in less than $20 \mathrm{~min}$.

The results shown in Figure 4 indicated that the enzyme completely retained its activity at $\mathrm{pH} 5$ and $\mathrm{pH} 6$ for more than $72 \mathrm{~h}$. However, the MCA decreased while the $\mathrm{pH}$ increased; after $12 \mathrm{~h}$ of incubation, the enzyme retained $77 \%, 68 \%$ and $50 \%$ of its activity at $\mathrm{pH} 7, \mathrm{pH} 8$ and $\mathrm{pH} 9$, respectively. The MCA was completely diminished after incubation for $12 \mathrm{~h}$ at $\mathrm{pH} 10$. The optimum $\mathrm{pH}$ for the MCE of B. subtilis (natto) Takahashi is different from that of the partially purified enzyme of other microorganism; it is $\mathrm{pH} 4, \mathrm{pH} 5.5$ and $\mathrm{pH} 11$ for the MCE of P. oxalicum
(Hashem 2000), M. baciliformis (Venera et al. 1997) and Nocardiopsis sp. (Cavalcanti et al. 2004) respectively. However, the $\mathrm{pH}$ stabilities for the $\mathrm{MCE}(\mathrm{s})$ of these microorganisms were rarely reported and obscure. The fact that the MCE of B. subtilis (natto) Takahashi showed a wide rang of $\mathrm{pH}$ stability, in that it retained more than $50 \%$ of its activity between $\mathrm{pH}$ 5-9 for more than $72 \mathrm{~h}$ at $35^{\circ} \mathrm{C}$, has made it more useful as a cheese-making coagulant because $\mathrm{pH}$-sensitive coagulants generally lead to reduced yields and defective cheese (Cavalcanti et al. 2004).

\section{Conclusions}

The MCE production by the B. subtilis (natto) Takahashi was increased significantly by 428\%, from $600 \mathrm{SU} / \mathrm{ml}$ in M1, a medium conventionally used in the literature, to 1048.02 SU/ml in the optimal medium developed by surface response methodology (RSM), indicating that RSM is proven to be a powerful and useful tool for optimizing the substrate concentration for enhancing MCE production. The MCE was successfully concentrated by application of ultrafiltration. The crude enzyme obtained after ultrafiltration showed two major bands between $25 \mathrm{kDa}$ and $30 \mathrm{kDa}$ on SDS-PAGE, which is consistent with many other MCE reported. The crude enzyme thus obtained showed $\mathrm{MCA}$ and MCA/PA ratio of 48,000 SU/g and 6,400, which are commensurate with those (MCA 26,667 SU/g and MCA/PA 6,667) of the commercial rennet. In addition, it had optimal $\mathrm{pH}$ and temperature at $\mathrm{pH} 6$ and $60^{\circ} \mathrm{C}$, and showed excellent $\mathrm{pH}$ and thermal stability. The data shown have suggested that B. subtilis (natto) Takahashi is an ideal strain for the production of the MCE that has potential as calf rennet substitutes and it is a good choice for further studies and industrial exploitations. 


\section{Competing interests}

'The authors declare that they have no competing interests'.

\section{Authors' contributions}

FCW participated in the design of the study, helped to perform the statistical analysis and drafted the manuscript. CWC carried out the experiments. ILS conceived of the study, and participated in its design and helped to draft the manuscript. All authors read and approved the final manuscript.

\section{Acknowledgements}

This work was supported partially by a grant (96-2628-B-212-001-MY3) from National Science Council of Taiwan.

\section{Author details}

${ }^{1}$ Department of Bioindustry Technology, Da-Yeh University, Changhua, Taiwan. ${ }^{2}$ Department of Environmental Engineering, Da-Yeh University, 168, University Rd., Dacun, Changhua 51591, Taiwan.

Received: 1 December 2012 Accepted: 20 January 2013 Published: 31 January 2013

\section{References}

Abdel-Fattah AF, Saleh SA (1979) Production and isolation of milk-clotting enzyme from Aspergillus versicolor. Zentralbl Bakteriol Naturwiss 134:547-550

Areces LB, Bonino MB, Parry MA, Fraile ER, Fernandez HM, Cascone O (1992) Purification and characterization of a milk-clotting protease from Mucor baciliformis. Appl Biochem Biotechnol 37:283-294

Arima K, Yu J, Iwasaki S (1970) Milk-clotting enzyme from Mucor pusillus var. Lindt. Methods Enzymol 19:446-459

Ayhan F, Celebi SS, Tanyolac A (2001) The effect of fermentation parameters on the production of Mucor miehei acid protease in a chemically defined medium. J Chem Technol Biotechnol 76:153-160

Baudys M, Erdene TG, Kostka V, Pavlik M, Foltmann B (1988) Comparison between prochymosin and pepsinogen from lamb and calf. Comp Biochem Physiol B 89:385-391

Birkkjaer H, Jonk P (1985) Technological suitability of calf rennet substitutes. Int Dairy Fed Bull 194:8-13

Box GEP, Wilson KB (1951) On the experimental attainment of optimum conditions. J Roy Statist Soc Ser B 13:1-45

Cavalcanti MTH, Martinez CR, Furtaso VC, Neto BB, Teixeira MFS, Lima-Filho JL, Porto ALF (2005) Milk-clotting protease production by Nocardiopsis sp. in an inexpensive medium. World J Microbiol Biotechnol 21:51-154

Cavalcanti MTH, Teixeira MFS, Lima-Filho JL, Porto ALF (2004) Partial purification of new milk clotting enzyme produced by Nocardiopsis sp. Biores Technol 93:29-35

Chang CW (2010) The study of the production of milk-clotting enzyme by Bacillus Subtilis Natto. Master thesis. Da-Yeh University, Changhua, Taiwan

Chazarra S, Sidrach L, López-Molina D, Rodríguez-López JN (2007) Characterization of the milk-clotting properties of extracts from artichoke (Cynara scolymus, L.) flowers. Int Dairy J 17:1393-1400

Crawford RJM (1985) Future developments in rennet and its use in the cheese factory. Int Dairy Fed Bull 194:14-23

D'Ambrosio D, Roddano R, Ungaro N, Riccio P (2003) Proteolytic and milk clotting activities in extracts obtained from the crustaceans Munida. J Mol Catal B: Enzym 22:145-150

Ding ZY, Liu SP, Gu ZH, Zhang L, Zhang KC, Shi GY (2011) Production of milk-clotting enzyme by Bacillus subtilis B1 from wheat bran. Afr J Biotechnol 10:9370-9378

ElBendary MA, Moharam ME, Ali TH (2007) Purification and characterization of milk clotting enzyme produced by Bacillus sphaericus. J Appl Sci 3:695-699

Escobar J, Barnett S (1993) Effect of agitation speed on the synthesis of Mucor miehei acid protease. Enzyme Microb Technol 15:1009-1013

Hashem AM (1999) Optimization of milk-clotting enzyme productivity by Penicillium oxalicum. Biores Technol 70:203-207

Hashem AM (2000) Purification and properties of a milk-clotting enzyme produced by Penicillium oxalicum. Biores Technol 75:219-222

He XL, Ren FZ, Guo HY, Zhang WB, Song X, Gan BZ (2011) Purification and properties of a milk-clotting enzyme produced by Bacillus amyloliquefaciens D4. Korean J Chem Eng 28:203-208

Khan MR, Blain JA, Patterson JDE (1979) Extracellular proteases of Mucor pusillus. Appl Environ Microbiol 37:719-724

Kunitz M (1947) Crystalline soybean trypsin inhibitor. II. General properties. J Gen Physiol 30:291-310
Li Y, Liang S, Zhi D, Chen P, Su F, Li H (2012) Purification and characterization of Bacillus subtilis milk-clotting enzyme from Tibet Plateau and its potential use in yak dairy industry. Eur Food Res Technol 234:733-741

Lopes A, Teixeira G, Liberato MC, Pais MS, Clemente A (1998) New vegetal sources for milk-clotting enzymes. J Mol Catal B: Enzym 5:63-68

Lowry OH, Rosebrough NJ, Farr AL, Randall RJ (1951) Protein measurement with the Folin phenol reagent. J Biol Chem 193:265-275

Maddox IS, Richert SH (1977) Use of response surface methodology for the rapid optimization of microbiological media. J Appl Bacteriol 43:197-204

Montgomery DC (1991) Response surface methods and designs. In: Design and Analysis of Experiments, 3rd edn. John Wiley \& Sons, New York, pp 521-563

Nagodawithana T, Reed G (1993) Enzymes in Food Processing, 3rd edn. Academic Press, San Diego, USA

Nouani A, Moulti-Mati F, Belbraouet S, Bellal MM (2011) Purification and characterization of a milk-clotting protease from Mucor pusillus: method comparison. Afr J Biotechnol 10:1655-1665

Porto ALF, Campos-Takaki GM, Lima-Filho JL (1996) Effects of culture conditions on protease production by Streptomyces clavuligerus growing in soy bean flour medium. Appl Biochem Biotechnol 60:115-122

Rao MB, Tanksale AM, Ghatge MS, Deshpande W (1998) Molecular and biotechnological aspects of microbial proteases. Microbiol Mol Biol Rev 62:597-635

Rogelj I, Perko B, Francky A, Penca V, Pungercar J (2001) Recombinant lamb chymosin as an alternative coagulating enzyme in cheese production. J Dairy Sci 84:1020-1026

Schallmey M, Singh A, Ward OP (2004) Developments in the use of Bacillus species for industrial production. Can J Microbiol 50:1-17

Shieh CJ, Phan-Thi LA, Shih IL (2009) Milk clotting enzymes produced by culture of Bacillus subtilis natto. Biochem Eng J 43:85-91

Shih IL, Shen MH (2006) Application of response surface methodology to optimize production of poly( $\varepsilon$-lysine) by Streptomyces albulus IFO14147. Enzyme Microb Technol 39:15-21

Shih IL, Van YT, Chang YN (2002) Application of statistical experimental methods to optimize production of poly( $\gamma$-glutamic acid) by Bacillus licheniformis CCRC 12826. Enzyme Microb Technol 31:213-220

Shih IL, Yu YT (2005) Simultaneous and selective production of levan and poly( $\gamma^{-}$ glutamic acid) by Bacillus subtilis. Biotechnol Lett 27:103-106

Shindo K, Arima S (1979) Studies on chymosin: I. Chromatographic purification and some properties of chymosin. Agri Biol Chem 28:A177-A180

Silva SV, Malcata FX (2005) Studies pertaining to coagulant and proteolytic activities of plant proteases from Cynara cardunculus. Food Chem 89:19-26

Silveira GG, Oliveira GM, Riberieo EJ, Monti R, Contiero J (2005) Microbial rennet produced by Mucor miehei in solid-state and submerged fermentation. Brazil Arch Biol Technol 48:931-937

Thakur MS, Karanth NG, Nand K (1990a) Production of fungal rennet by Mucor miehei using solid state fermentation. Appl Microbiol Biotechnol 32:409-413

Thakur MS, Karanth NG, Nand K (1990b) Studies on the production of microbial rennet by solid state fermentation. Trans Mycol Soc ROC 5:13-28

Tubesha ZA, Al-Delaimy KS (2003) Rennin-like milk coagulant enzyme produced by a local isolate of Mucor. Int J Dairy Technol 56:237-241

Venera GD, Machalinski C, Zumárraga H, Biscoglio MJ, Bonino DJ (1997) Further characterization and kinetic parameter determination of a milk-clotting protease from Mucor bacilliformis. Appl Biochem Biotechnol 68:207-216

Vishwanatha KS, Appu Rao AG, Singh SA (2010) Production and characterization of a milk-clotting enzyme from Asoergillus oryzae MTCC 5341. Appl Microbiol Biotechnol 85:1849-1859

Weber K, Osborn M (1969) The reliability of molecular weight determination by dodecylsulfate-polyacryamide gel electrophoresis. J Biol Chem 244:4406-4412

Yoshimoto T, Fukumoto J, Tsuru D (1971) Bacterial proteases. Enzymic and physicochemical properties of the alkaline protease from Bacillus natto. Int J Protein Res 3:285-295

Yu PJ, Chou CC (2005) Factors affecting the growth and production of milkclotting enzymes by Amylomyces rouxii in rice liquid medium. Food Technol Biotechnol 43:283-288

Zhang ZG, Wang CZ, Yao ZY, Zhao JF, Lu FX, Yu GM, Lan WJ, Lu ZX (2011) Isolation and identification of a fungal strain QY229 producing milk-clotting enzyme. Eur Food Res Technol 232:861-866

doi:10.1186/2193-1801-2-33

Cite this article as: Wu et al:: Optimization of the production and characterization of milk clotting enzymes by Bacillus subtilis natto. SpringerPlus 2013 2:33. 